Monika Zamachowska, Andrzej Śródka

Katedra Historii Medycyny CM UJ, Kraków

\title{
LUDWIK HIRSZFELD (1884-1954)
}

Ludwik Hirszfeld urodził się 5 sierpnia 1884 roku w Warszawie w rodzinie Stanisława, kupca i przemysłowca oraz Jenny z Ginsbergów. Rodzina Hirszfeldów była mocno wrośnięta w polską kulturę, czego dobitnym przykładem był stryj Ludwika - Bolesław, chemik, zasłużony działacz oświatowy, współzałożyciel kilku stowarzyszeń o takim charakterze, a zwłaszcza Związku Młodzieży Polskiej „Zet”. Szwagrem Ludwika, mężem jego siostry Róży, był wybitny neurolog Władysław Sterling, profesor psychopatologii dziecka Wolnej Wszechnicy Polskiej w Warszawie ${ }^{1}$.

Po bankructwie ojca rodzina Hirszfeldów przeniosła się do Łodzi, gdzie w 1902 roku Ludwik ukończył gimnazjum humanistyczne. W Łodzi zaangażował się w działalność konspiracyjnych kółek patriotyczno-oświatowych. W tych latach poznał uczennicę szkoły tańca - Hannę Kassmannównę, którą kilka lat później poślubił. Hanna Hirszfeldowa również ukończyła medycynę, a po II wojnie światowej została profesorem pediatrii Uniwersytetu i Akademii Medycznej we Wrocławiu.

Zaraz po maturze Hirszfeld wyjechał na studia do Niemiec. W Würzburgu przez dwa lata studiował medycynę, m.in. u Theodora Boveriego, twórcy chromosomowej teorii dziedziczności i u profesora histologii Philippa Stöhra, a od 1904 do 1907 roku w Berlinie medycynę i filozofię, słuchając wykładów Ernsta Bumma z ginekologii, Ulricha Friedemanna z bakteriologii i Johannesa Ortha z patologii ${ }^{2}$. Hirszfelda nie interesował praktyczny aspekt medycyny, czyli dobrze zarabiająca prywatna praktyka. Marzył o pracy naukowej, konkretnie chciał zostać serologiem i dokonywać odkryć w tej zupełnie nowej i niezbadanej dziedzinie nauki. Swoją przyszłość zaplanował pod wpływem impulsu, kiedy to pewnej nocy przeczytał jedno z pierwszych i dość kontrowersyjnych dzieł z tego zakresu, monografię Oppenheima Toksyny i antytok-

1 PSB T. 9, Kraków 1960-1961 s. 533-535.

2 Biographisches Lexikon, Berlin, Wien 1880-1930, s. 637.

Kwartalnik Historii Nauki i Techniki R. 63: 2018 nr 1 s. 141-149 
syny. Miał wówczas 21 lat i niezwykle wyrozumiałą i rezolutną żonę, która nie tylko pracowała jako pediatra, ale też utrzymywała ich oboje z korepetycji, choć zdarzyło się, że dla opłacenia swoich wydatków naukowych musiał zastawić własny zegarek ${ }^{3}$.

W roku 1907 otrzymał w uniwersytecie w Berlinie stopień doktora medycyny na podstawie pracy Untersuchungen über die Hämmaglutination und ihre physikalischen Grundlagen (1907). W tym samym roku przeniósł się do Instytutu Badania Raka w Heidelbergu, gdzie został zatrudniony najpierw jako asystent Oddziału Parazytologii (do 1909 r.), a następnie Oddziału Serologii (do 1911 r.). Początki pracy naukowej były bardzo trudne. Hirszfeld, który wielokrotnie odrzucał proponowane tematy doktoratu, w Instytucie Badania Raka został skierowany do obserwacji płytki z amebami hodowanymi na słomie, oraz sekcjonowania myszy w celu ustalenia statystycznego występowania pasożytów w ich ciałach. Prace te nie nosiły znamion badań naukowych, ale Hirszfeld (tak zresztą postępował przez całe życie), pomimo ogromnego rozczarowania, postanowił uczciwie wywiązać się ze swoich obowiązków. W ten sposób dokonał bardzo ważkich odkryć rzucających nowe światło na biologię ameb. Kluczem do sukcesu były nie tylko nowe metody barwienia, ale przede wszystkim nowatorska metoda obserwacji tych pierwotniaków polegająca na włożeniu pomiędzy szkiełko podstawowe a szkiełko nakrywkowe włoskowatej rurki. W miejscu tym wytwarzało się małe jeziorko. Ameby zapuszczające się w jego pobliże zmieniały kształt i w postaci wiciowców przepływały na drugi brzeg ${ }^{4}$. Było to zupełnie pionierskie odkrycie, jednak nie zaspakajające ambicji naukowych Hirszfelda. Całkiem przypadkiem poznał wtedy pracującego $\mathrm{w}$ instytucie serologa $\mathrm{dr}$. Emila von Dungerna. Panowie zaprzyjaźnili się tak bardzo, że Hirszfeld nawet wyswatał mu żonę. To właśnie Dungern zaproponował mu asystenturę w swoim zakła$\mathrm{dzi}^{5}$. Współpraca profesora z nowym asystentem przyniosła rewelacyjne rezultaty. Pierwsze prace badawcze uczonych dotyczyły odporności tkanek, następne grup krwi, i doprowadziły do ustalenia grup głównych u ludzi i zasad ich dziedziczenia. W stosunku do prac doświadczalnych na zwierzętach przedstawiały one niezwykłą trudność. Najpierw należało namówić badanego i jego rodzinę do oddania krwi, a potem dopytać delikatnie o szczegóły pożycia małżeńskiego, które miały oczywiste implikacje w sprawach dziedziczności. Sprawy nie polepszał fakt, że badanymi byli profesorowie Zakładu i ich rodziny ${ }^{6}$.

W 1911 roku Hirszfeld postanowił spróbować własnych sił i związał się z uniwersytetem w Zurychu jako asystent Katedry Higieny. Ważnym czynnikiem, który wpłynął na jego decyzję była również możliwość poznania innych zagadnień z zakresu higieny i bakteriologii, praca z młodzieżą i możliwość habilitacji . Tu w 1914

\footnotetext{
${ }^{3}$ L. H i r s z feld: Historia jednego życia. Kraków, 1946 s. 11-12.

${ }^{4}$ Tamże, s. 13-14.

${ }^{5}$ Tamże, s. 15-17.

${ }^{6}$ Tamże, s. 19-23.

${ }^{7}$ Tamże, s. 23.
} 
roku habilitował się z higieny i nauki o odporności na podstawie rozprawy Ueber Anaphylaxie und Anaphylatoxin und ihre Beziehungen zu den Gerinnungsvorgangen. Odkrył i opisał w niej nowy odczyn kiłowy (tzw. koaguloreakcję), polegający na niszczeniu zawiesiny przez surowice kiłowe oraz przedstawił nową teorię działania komplementu (dopełniacza) i teorię fizykalną odczynu Wassermanna. Hirszfeld wyjaśnił także istotę anafilatoksyny.

Do 1919 roku był etatowym docentem uniwersytetu w Zurychu, gdzie od 1914 roku wykładał choroby zakaźne i serologię. Ogromną wagę przykładał do pracy pedagogicznej. W swoich wspomnieniach po latach napisze:

W Zurychu pokochałem pracę pedagogiczną i poza pracą naukową moje najlepsze chwile spędzałem z młodzieżą. Czułem się wówczas jak ogrodnik co chodzi po kwietnym ogrodzie dusz ludzkich, tu podeprze kwiat, tam chwast jakiś wyrwie, gdy zaś widzi jakąś piękną odmianę, otacza ją specjalną opieką i czułością. Jeżeli czasem marzyłem o tym, jak pragnąłbym żyć w pamięci młodzieży, to nigdy jako profesor, ani broń Boże - dyrektor, ale jako ogrodnik dusz ludzkich. I myślałem, że zadaniem życia jest zasłużyć na to ${ }^{8}$.

W latach 1911-15 kierował badaniami i akcjami epidemiologicznymi, dotyczącymi występowania wola endemicznego w Szwajcarii. Podobne prace prowadził po II wojnie światowej w Polsce (1947-52).

W lutym 1915 r. Hirszfeld wziął urlop i wyjechał do Serbii, gdzie ludność dziesiątkował dur plamisty. Szybko rozprzestrzeniająca się epidemia wyludniała wsie i miasta, a lekarze i pielęgniarki umierali tak samo jak pozostali. Wkrótce znalazł się w środku epidemii w miejscowości Valiewo. Obiecaną pracownię stanowił jeden pokój i mała skrzynka zawierająca cieplarkę na 50 probówek i kilka odczynników. Chorzy szpitala zakaźnego leżeli po kilku na jednym łóżku lub na podłodze. Nie nadążano z grzebaniem umarłych. Stosy trupów leżały w pobliżu szpitala. Skromna pracownia Hirszfelda szybko stała się małym ośrodkiem naukowym. Z blaszek do nafty skonstruował aparaty do sterylizacji, z tektury - statywy. Wkrótce udało mu się wyhodować jedne z pierwszych szczepów paratyfusu A. Epidemię w Valiewie udało się opanować, gdy wraz z miejscowymi lekarzami wydezynfekował za pomocą siarki wszystkie mieszkania i wszystkie rzeczy w 4-tysięcznym miasteczku ${ }^{9}$. Po kilku miesiącach pracy dołączyła do niego żona. Pod koniec wojny zdecydowali, że wraz z wycofującą się armią serbską ruszą za nią jako formacja szpitalna. Wybrali długą i ryzykowną tułaczkę, choć mogli pozostać na miejscu i wrócić spokojnie do Szwajcarii. Nie potrafili pozostawić rannych i umierających bez pomocy. Wraz z nimi przedzierali się przez góry Albanii, przez 12 dni walcząc o przetrwanie w surowych warunkach górskiej zimy. Cudem nie zginęli z zimna i głodu. Wreszcie dotarli do albańskiego portu w San Giovanni di Medua, skąd zostali ewakuowani statkiem do

\footnotetext{
${ }^{8}$ Tamże, s. 28-29.

${ }^{9}$ Tamże, s. 35-37.
} 
Włoch, a następnie wrócili do Zurychu ${ }^{10}$. Hirszfeld rozpoczął tutaj badania nad zastosowaniem soli kuchennej u osób przy wstrząsie pokrwotocznym. Jednak nie potrafił już cieszyć się nauką akademicką, tak jak poprzednio. Wkrótce wraz z żoną wyjechał na Korfu. Prowadził tam pracownię mikrobiologiczną przy szpitalu dla chorych zakaźnych. Pani Hirszfeldowa, która jako wolontariusz została wcielona do armii włoskiej, prowadziła własny oddział. Wielonarodowość armii, z którą przypadło im współpracować, umożliwiło Hirszfeldowi badania statystyczne nad częstością występowania głównych grup krwi wśród różnych ras i narodów, co w innych warunkach właściwie nie byłoby możliwe. W trakcie badań mikrobiologicznych zachorował na paratyfus A, który omal nie skończył się dla niego śmiertelnie, ale na szczęście pozostawił po sobie jedynie - jak to sam określał - satysfakcję zakażenia bardzo rzadką w Europie chorobą. Chorował również na malarię i gorączkę papatacci. Za to preparaty zimnicy, które udało mu się uzyskać, zaliczał do tak pięknych i różnorodnych, że mógł się im przyglądać godzinami. Używał ich potem w Polsce jako pomocy naukowych dla studentów ${ }^{11}$.

Po zakończeniu wojny, gdy tylko został zwolniony z obowiązku pracy w szpitalu, wrócił wraz z żoną do niepodległej Ojczyzny. Naturalnie pierwsze kroki skierował do Warszawy, do domu rodzinnego.

Ogarnęło mnie wzruszenie, którego nie jestem w stanie opisać. Pierwsze okrzyki: »herbata, bułeczki«, wzruszają mnie do łez. Wracam przecież do kraju po 15 latach. W Warszawie wychodzę z dworca, chciałbym uściskać każdego przechodnia. Głosy kobiece, jakiś charakterystyczny alt odczuwam jak muzykę. Wchodzę do mieszkania matki. Nie zastaję jej: pielęgnuje umierającą babkę. Matka nie wiedziała dokładnie kiedy wrócę. Ale stół jest nakryty i na nim wszystko, co w dzieciństwie lubiłem, żaden szczegół nie jest pominięty. W jej wspomnieniu żyłem jako mały jedynak. I wówczas zapomniałem i o wojnie, i o nauce, i o Szwajcarii, poczułem się małym chłopcem, szczęśliwym, że ktoś wie, że lubię polędwicę...I rozpłakałem się jak dziecko. Taki był mój powrót do kraju"12.

W 1920 roku urodziła się jedyna córka Hirszfeldów. Mieszkali wtedy w centrum Warszawy, w Alejach Jerozolimskich. Z okien mieszkania rozpościerał się widok na mur oficyny, a do pokoju wpadały odgłosy z sąsiednich mieszkań. Przez siedem lat Hirszfeldowie marzyli o domu z widokiem na słońce. Wreszcie pewnej lipcowej nocy, spacerując po moście Poniatowskiego, odkryli „zaczarowaną otchłań, pełną zapachów kwitnących lip i łąk”. To była Saska Kępa. W kilka dni potem stali się właścicielami jednej z parceli przy ulicy Obrońców, gdzie wkrótce stanął domek z ogródkiem ${ }^{13}$.

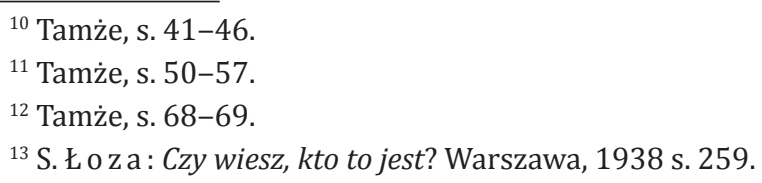


Okna naszej sypialni wychodziły na wschód, gdyż pragnąłem rozpoczynać dzień od widoku budzącego się życia. Z rana zrywałem róże, pokryte jeszcze kroplami rosy i dawałem je żonie. Była to moja pieśń dziękczynna.

Na Saskiej Kępie Hirszfeldowie spędzili najpiękniejsze lata swojego życia ${ }^{14}$.

W 1920 roku Hirszfeld objął kierownictwo Państwowego Zakładu Badania Surowic w Warszawie, a po przekształceniu go trzy lata później w Państwowy Zakład Higieny stanął na czele Oddziału Badania Surowic Działu Bakteriologii i Medycyny Doświadczalnej; dyrektorem tego Działu był do wybuchu wojny. W latach 1926-33 był zastępcą dyrektora Państwowego Zakładu Higieny. W ten sposób zrealizowały się jego ambicje pracy dla kraju, w warunkach godnych naukowca. Na przeszkodzie w objęciu dyrekcji tej placówki stanęło żydowskie pochodzenie Hirszfelda.

Drugim marzeniem Hirszfelda była praca dydaktyczna z młodzieżą. W latach 1924-31 kierował Katedrą Bakteriologii Wolnej Wszechnicy Polskiej, a w 1931 roku został profesorem tytularnym Uniwersytetu Warszawskiego; w obu uczelniach oraz w Szkole Higieny w Warszawie wykładał bakteriologię i immunologię. W swojej pracy przykładał szczególną wagę do osobistej wizytacji terenów objętych epidemiami i do osobistego szkolenia lekarzy powiatowych. Za niezbędne uważał również terenowe szkolenia studentów, którzy pod okiem epidemiologów wyjeżdżali na kilkudniowe praktyki na tereny zakaźne, gdzie zbierali wywiady i pobierali próbki, które sami badali po powrocie na uczelnię ${ }^{15}$.

W 1928 roku przewodniczył Sekcji Grup Krwi Międzynarodowego Zjazdu Serologicznego w Amsterdamie. W latach 1923-46 był redaktorem naczelnym „Medycyny Doświadczalnej i Społecznej".

Jako specjalista od badań nad grupami krwi został poproszony o opinię w słynnej sprawie Gorgonowej. Była to ponowna ekspertyza materiału dowodowego, jaki stanowiła chusteczka oskarżonej zabrudzona krwią. Hirszfeld wiedział z doświadczenia, że właściwości grupowe można wykryć również na materiałach, dotykanych przez daną osobę. Chusteczka była przesycona składnikami grupowymi niezależnie od plam krwi. Dlatego też dowód oparty jedynie na ekspertyzie grup krwi nie powinien być brany pod uwagę jako ostateczny. Najważniejsze w sprawie było to, że opinia podważyła poprzednią ekspertyzę, wydaną przez eksperta lwowskiego. Hirszfeld w związku z tym stał się postacią medialną, co odbierał zresztą dość niechętnie ${ }^{16}$.

Warto również wspomnieć, że był inicjatorem zakładania ośrodków krwiodawstwa w Polsce. Udało mu się również wprowadzić pierwsze w Europie przepisy prawne regulujące te procedury.

\footnotetext{
${ }^{14}$ L. Hirs z feld: Historia... s. 157-160.

${ }^{15}$ GBL L. 2879.

${ }^{16}$ L. H ir s z feld: Historia... s. 88-89.
} 
Podczas II wojny światowej, od marca 1941 do sierpnia 1942 roku, przebywał w getcie warszawskim, gdzie współorganizował Towarzystwo Lekarskie i w jego ramach prowadził wykłady z medycyny oraz współpracował z Radą Zdrowia w zakresie zwalczania duru plamistego, gruźlicy i innych chorób zakaźnych. W tym czasie przebywał na terenie parafii kościoła Wszystkich Świętych przy pl. Grzybowskim, gdzie współpracował z jej proboszczem księdzem Michałem Godlewskim w prowadzonych przez niego akcjach charytatywnych. Z getta udało mu się wydostać i przez pewien czas ukrywał się pod zmienionym nazwiskiem w domu Laury z Przedpełskich Kenigowej, żony Mariana Keniga, działacza PPS i dowódcy Robotniczej Brygady Obrony Warszawy. Zagrożony aresztowaniem, przeniósł się do Starej Miłosnej koło Warszawy, a następnie do Klembowa koło Tłuszcza, gdzie mieszkał u gospodarza Stanisława Kaflika, podając się za urzędnika-dezynfektora. Później, do 1944 roku, ukrywał się w Kamiennej w Ziemi Pińczowskiej. Tutaj zmarła też w wieku 23 lat jego jedyna córka, co było osobistą tragedią Profesora i naznaczyło bolesny ślad w jego całym późniejszym życiu. W roku 1943 spisał swoją literacką autobiografię, która ukazała się w roku 1946 pt. Historia jednego życia.

Po zakończeniu działań wojennych Uniwersytet Marii Curie-Skłodowskiej w Lublinie powołał go w 1944 roku na kierownika Katedry Mikrobiologii Lekarskiej i prorektora uczelni. Po roku przeniósł się do Wrocławia, do domu przy ulicy Wittyga 11. Na tamtejszym uniwersytecie objął Katedrę Mikrobiologii i piastował ją do śmierci (od 1950 roku w Akademii Medycznej); w roku akademickim 1945/46 pełnił funkcję dziekana Wydziału Lekarskiego. W uczelniach tych prowadził wykłady z serologii, immunologii, bakteriologii i patologii ciąży. W powstałym w lutym 1954 roku Instytucie Immunologii i Terapii Doświadczalnej PAN stanął na czele Zakładu Grup Krwi, ale kierował nim już tylko przez miesiąc. Zmarł 7 marca 1954 roku we Wrocławiu.

Wykształcił grono wybitnych mikrobiologów. Do jego uczniów należy Róża Amzelówna, świetnie zapowiadająca się badaczka grup krwi. Znała w mowie i piśmie siedem języków, miała dar porywającego wykładu. Pomagała Hirszfeldowi organizować stacje krwiodawcze podczas oblężenia Warszawy. Zginęła wraz z matką po ucieczce z getta. Również grupami krwi, lecz bardziej w aspekcie antropologicznym, zajmowała się Wanda Halberówna. Z Hirszfeldem współpracowała w Wolnej Wszechnicy Polskiej i w Państwowego Zakładzie Badania Surowic. On sam uważał ją za najzdolniejszego swego asystenta na tym polu. Na pograniczu badań patofizjologii krwi i patologii ciąży stały prace Andrzeja Kelusa, a prace Hirszfelda nad durem kontynuował Władysław Mański. Feliks Milgrom objął po śmierci Hirszfelda dyrekcję Instytutu Immunologii i Terapii Doświadczalnej PAN. W latach 50. został zmuszony do emigracji do USA, gdzie pracował jako profesor immunologii Uniwersytetu Stanowego w Nowym Jorku. Jerzy Morzycki przed wojną kierował filią Państwowego Zakładu Higieny w Poznaniu. Wybitnym uczniem Ludwika Hirszfelda był 
Bernard Zabłocki, profesor mikrobiologii Uniwersytetu Łódzkiego. Wsławił się on wyodrębnieniem endotoksyny pałeczki duru brzusznego i określeniem jej struktury chemicznej. Pod koniec lat 40. zorganizował akcję badań serologicznych u około 600 tys. mieszkańców Dolnego Śląska pod kątem zakażenia kiłowego. Po II wojnie światowej zaangażował się w akcje pokojowe (sprawę „obrony pokoju” uważał za ideę, a nie za hasło) i w popieranie ugrupowań demokratycznych. Był głębokim humanistą, przez całe życie pozostawał „pod inspiracją chrześcijaństwa i pod inspiracją ideałów czysto ludzkich, w które wierzył niezłomnie" (A. Rogalski). W chrześcijaństwie widział drogę wyzwalającą dążenie do dobra jako absolutu i filozofię szacunku dla życia ${ }^{17}$.

Ludwik Hirszfeld był pionierem badania grup krwi, twórcą nowej dziedziny nauki - seroantropologii oraz polskiej szkoły immunologicznej. Zakres jego zainteresowań naukowych jest ogromny, dotyczył serologii, immunopatologii, bakteriologii lekarskiej, immunologii, onkologii doświadczalnej, patofizjologii krwi, serologii sądowej, patologii ciąży i genetyki populacyjnej. Wraz z niemieckim internistą baronem Emilem von Dungernem w latach 1910-11 odkrył i opisał dziedziczenie mendlowskie zróżnicowania grupowego krwi: A, B, AB i O (przyjęte w 1928 roku na całym świecie) oraz odkrył podgrupy A1 i A2 w obrębie grupy A w zależności od stopnia wiązania aglutyniny alfa. Prace Ueber eine Methode, das Blutverschiedener Menschen serologisch zu unterscheiden (1910) i Ueber gruppen spezifische Strukturen des Blutes... (1911) są pionierskie dla nowoczesnej nauki o grupach krwi.

Niezależnie od Edmunda Biernackiego opisał w 1917 roku zjawisko opadania erytrocytów, zależne od właściwości osocza, od ich liczby i od wzajemnego stosunku osocza i krwinek oraz zróżnicował szczegółowo opadanie krwinek czerwonych i aglutynację (Ueber ein neues Blutsymptom bei Malariakrankheit).

Całkowicie nowatorskie badania Ludwik i Hanna Hirszfeldowie przeprowadzili w latach 1918-19. W pracach Essai d'application des méthodes sérologiques au problème des races (1918-19) i Serological Differences between the Blood of Different Races (1919) opisali oni nierównomierność rozmieszczenia cech grupowych krwi w rozmaitych populacjach i przedstawili hipotezę, według której zróżnicowanie serologiczne ludzi jest odbiciem zróżnicowanych przystosowań gatunku ludzkiego w przebiegu ewolucji, a niejednakowy procent występowania grup krwi w populacjach - odbiciem gwałtownych procesów migracyjnych. Co równie ważne, stwierdzili niezmienność składu serologicznego grup krwi człowieka przy wykrzyżowaniu się odmiennych składników w warunkach niezadziałania procesów selekcyjnych.

Czysto bakteriologiczna była praca A New Germ of Paratyphoid (1919), w której niezależnie od Janusza Supniewskiego przedstawił odkrycie przez siebie, wyhodowanie i opis mikrobiologiczny pałeczki duru rzekomego. Pałeczka ta nosi dziś nazwę Salmonella hirszfeldi.

${ }^{17}$ Encyklopedia Katolicka, t. 6, Lublin, 1993 s. 936-937. 
Kolejne badania dotyczyły szeroko pojętej immunopatologii. W 1925 roku Hirszfeld wraz z Henrykiem Zborowskim formułują koncepcje konfliktu serologicznego. Pionierskie są tu dwie ich prace: Gruppenspezifische beziehungen zwischen Mutter und Frucht und elektive Durchlässigkeit der Placenta (1925) i O współżyciu serologicznem matki i płodu (1926). Autorzy wysunęli w nich tezę o możliwości istnienia konfliktu serologicznego między matką a płodem i wprowadzili pojęcie ciąży heteroswoistej. Wykazali przy tym związek przyczynowy erytroblastozy z pierwotnym uszkodzeniem płodu i występowaniem zespołu poronieniowego jedynie jako skutku alergizacji matki przez odmienne alergeny płodu.

Badania w zakresie onkologii doświadczalnej Hirszfeld prowadził z jednym z najwybitniejszych później uczonym w tej dziedzinie - Józefem Laskowskim. Szczególne miejsce zajmują „Badania serologiczne nad nowotworami człowieka” (1929, z W. Halberówną i J. Laskowskim). Opisano tu zjawisko rozprzestrzeniania się izoaglutynin anty-A w różnych narządach człowieka i stwierdzono w tzw. narządach grupowo względnych związek między obecnością aglutynin a „bliskością” nowotworu. Dodatkowo potwierdzono swoistość tkanki nowotworowej i zmiany jej biochemizmu w wyniku różnych procesów wstecznych, prowadzących do zmiany jej antygenowości. Autorzy wykazali także odwrotnie proporcjonalną zależność między stopniem anaplazji a nasileniem reakcji serologicznej nowotworu.

Jego bardzo głęboko sięgające badania serologiczne pozwoliły mu na wkraczanie z tą tematyką na pola odległe od uprawianej przez siebie mikrobiologii, na przykład medycyny sądowej i genetyki populacyjnej. W pracy $O$ sposobach i technice stwierdzania właściwości grupowych w plamach krwi i płynach ustroju (1931, z R. Amzelówną) wykazał obecność substancji grupowych w innych płynach ustrojowych niż krew oraz opracował metodę identyfikacji cech grupowych krwi w śladach krwawych. Z kolei w Hauptprobleme der Blutgruppenforschung (1933) opracował monograficznie zagadnienie indywidualnego zróżnicowania serologicznego w obrębie gatunku i konstytucyjnego uwarunkowania reakcji serologicznych organizmu. W 1938 roku przedstawił oryginalną teorię plejad, według której istnieją cechy grupowe krwi o jednakowej ilości substancji $0 \mathrm{w}$ erytrocytach i starającą się wyjaśnić występowanie układów grupowych w krwinkach (Uber das Wesen der 0-Eigenschaft und ihre Bedeutung für die Durchschlagkraft, 1938, z Z. Kostuchem). Kontynuował te badania jeszcze po wojnie m.in. w pracy z I. Lille-Szyszkowicz Badania nad immunologiq siary (1948). Autorzy stwierdzili w niej, że siara - w przeciwieństwie do mleka i surowicy - zawiera przeciwciała również dla krwinek czerwonych własnych i wszystkich krwinek grupy 0 .

Ludwik Hirszfeld był autorem trzech książek: Grupy krwi w zastosowaniu do biologji, medycyny i prawa (1934), Dochodzenie ojcostwa w świetle nauki o grupach krwi... (1948) i Immunologia ogólna (1948, wyd. II - 1949). Tę ostatnią należy traktować jako całkowicie oryginalny podręcznik tego przedmiotu. Określił w nim zja- 
wisko nabywania odporności jako wyraz dojrzewania układu immunologicznego z uwzględnieniem swoistych i nieswoistych bodźców egzogennych. W konsekwencji rozwinął teorię serogenezy, czyli zjawiska narastania przeciwciał fizjologicznych. Znalazły się tam wysoce oryginalne poglądy, jak uznanie prawa najmniejszego cierpienia jako zasady aktywności makro- i mikroorganizmów, a symbiozy nie tylko jako etycznie wyższej formy współżycia, ale i biologicznie rozsądniejszej od pasożytnictwa. W 1946 roku ukazała się literacka autobiografia Historia jednego życia (wyd. IV - 1989). Paweł Jasienica napisał reportaż o nim i o jego zakładzie - Konflikty ludzkiej krwi, kontrowersyjny i żywo dyskutowany, a także książkę Opowieści o żywej materii (1954) i wstęp do jego Myśli (1964). W 1985 roku ukazała się książka Grzegorza Fedorowskiego Ludwik Hirszfeld.

Za całość dorobku naukowego, a zwłaszcza za wkład naukowy do akcji masowego zwalczania chorób wenerycznych i do diagnostyki duru brzusznego w 1950 roku otrzymał nagrodę państwową I st. oraz został doktorem honoris causa uniwersytetów w Pradze (1951) i w Zurychu (1951). Był odznaczony Krzyżem Komandorskim jugosłowiańskiego Orderu Św. Sawy (1918), jugosłowiańskim Orderem Orła Białego (1928) i Krzyżem Komandorskim Orderu Odrodzenia Polski (1951). W latach 1922-31 był sekretarzem Polskiego Towarzystwa Biologicznego, a w 1931-35 prezesem Polskiego Towarzystwa Mikrobiologów i Epidemiologów. W 1946 współzałożył Wrocławskie Towarzystwo Naukowe i do śmierci był jego wiceprezesem. Był też członkiem honorowym Akademii Nauk w Nowym Jorku, Towarzystwa Naukowego w Charkowie, Towarzystwa Lekarskiego w Belgradzie i Francuskiego Towarzystwa Alergistów oraz członkiem korespondentem Wiedeńskiego Towarzystwa Mikrobiologów ${ }^{18}$. Był członkiem zwyczajnym TNW (1930), członkiem rzeczywistym PAN (1952) ${ }^{19}$, w 1945 roku odmówił natomiast kandydowania na członka PAU. W latach 1952-54 wchodził w skład Prezydium PAN oraz przewodniczył Podsekcji Podstawowych Nauk Lekarskich Komitetu Nauk Medycznych PAN. Jego imieniem nazwano Instytut Immunologii i Terapii Doświadczalnej PAN oraz ulice na Wyżynach w Warszawie i na Gajowicach we Wrocławiu.

\footnotetext{
${ }^{18}$ Arch. PAN III-157.

${ }^{19}$ Rocznik TNW, 23:1930 s. 53-58; 46:1983 s. 215-221.
} 